Final Word on the Stem Pessary for Amenorrhoea, Dysmenorrhos, Sterility. Etc.-J. H. Carstevs (Jour. Amer. Mred. Assoc., 1909, liii, 1730) has written a fourth paper on the suhject of the use of the stem pessary for various uterine fuactional ahaormalities. For ameaorrhos, premature atrophy, dysmenorrhoen, displacements of the uterus, and sterility He stroagly recommends the application of the stem pessary. In some instances its retention for one to two years is advised. He regards pelvie inflammations as contra-indicating the use of the stem pessary.

\title{
DERMATOI OGY.
}

\author{
UNDER THE CHATGE OF \\ LOUIS A. DUHRING, M.D.,

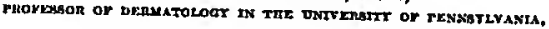 \\ AND \\ MIILTON B. HARTZELL, M.D.,

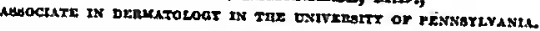

Lupus or Tertiary Syphilis? Sarcoma or Primary Syphilis?-Under this heading A. Nerssen (Berl. Klin. Woch., August 16, 1909) discusses the differential diagnosis, giving thenotes of a case of supposed lupus in which existing syphilis was not dingnosticated for two years. When there exists a suspicion of syphilis, he advises energetic mercurial and iodide treatment. Nasal disense first manifesting itsclf in a woman as late as the age of forty-one is more likely to be syphilis than lupus. A negntive history, especially in women, does not exclude syphilis. The author advises the employment of the subcutaneous tubereulia test in all instances of a superficial discase suspected of heing tuherculosis. A case is cited in which a large red warty patch had heea ohserved for two years on a young man and the dingnosis of tuhcrculosis verrucosa made, hut no reaction followed tubereulin up to $5 \mathrm{mg}$., hut the Wasserman test proved that syphilis existed, and recovery followed the usual internal remedies. A case is referred to in which a woman was helieved to have a sarcoma of the uterus, the ruicroscopic examination pointing to that disease, and hysterectomy was performed. Later, a papular syphilodeum appeared. The Wassermann test hefore the operatioa would have indicated the necessity for an antisyphilitie treatment.

Bxperimental Studies Ooacerning Tuberculosis of the Shin.-LewaxDowsKT (Archiv f. Dermat. und Syph., 1909, xcviii, Heft 2 and 3), who has made a somewhat ertensive study of the results following the inoculation of human and hovine tubercle bacilli into the skin of rahhits and guinea-pigs, has fouad that such inoculation whea properly performed always leads to a local tuberculosis of the skin. The result of the inoculation is dependent upon the varying virulence of the strain of the hacilli employed and upon racial and individual differences of the 
animals inoculated. The typical inoculation ulcer appears in guineapigs only in the second week, and may last uatil the death of the animal or it may beal over. In the latter event the small red-brown discolored spot remaining still coatains tuberculous tissue and is inoculable. Tuberculosis of the lympb cords only appears after the lympb-glands in the neigbborbood are affected, and this may lead to the formation of nodules with crateriform ulcers which only beal in the last days of the animal's life. In rabbits, in addition to ulcers, inoculation produces foci similar to lupus or, according to location, tuberculosis verrucosa. Intravenous injections iato the engorged ear of the rabbit may produce a papular eription on the skin of the ear, which undergoes spontaneous involution and contains bacilli only in the beginning (tuberculide-like lesions). "After similar injections with bovine bacilli a true tuberculosis occurs. Infection of the skin with bovine bacilli leads in rabbits always to general tuberculosis, but infection with buman bacilli pursues a different course; even intravenous injection is not always followed by gencral tuberculosis. Of internal organs, the lungs are almost always affected in rabbits after cutaneous infection. Histologically caseation is almost al ways wanting in the skin. In animals which bave undergoae a cutaneous iaoculation, subsequent inoculations, if they are made some time after the first one, take effect less vigorously than the first, unless tbe later ones are made with bovine bacilli. This relative immunity of the skin also appears after intraperitoneal inoculation.

Dermatitis Eerpetiformis.-Boonow (Archiv f. Dermat. und Syph., 1909, xcriii, Heft 2 and 3 ) reports a case of dermatitis herpetiformis with extensive eruption which, beginning a cutely in a woman with carcinoma uteri, began to undergo regression coincidently with the employment of disinfecting vaginal douches, the internal administration of calcium chloride, and the local use of astringent salves and compresses. An abrupt ending of the cutaneous affection and fall in the elevated temperature followed immediately upon an operation in which the entire visible, partly necrotic mass of the tumor was removed. Recurrence of the growth, wbich caused the death of the patient, was not followed by a return of the eruption. The author regards the case as a toxidermia proceeding from the necrotic tumor of the uterus, from wbich bacterial products reached the circulation, a view wbich the results of treatment support. Sbould future observations of a similar nature be made, the author believes they would furnisb ground for more closely associating dermatitis berpetiformis and impetigo berpetiformis.

The Trestment of Itching Dermatoses, Bspocially Trade Eczema, with Undilutad Conl Tar.-Chajes (Dermat. Ztschr., 1909, xvi, Heft 9), wbo bas employed coal tar in the treatment of 64 cases of various diseases of the skin, such as eczema, lichen planus, prurigo, and pruritus biemalis, fiads that it is an excellent and quickly acting remedy in many acute and chronic itching affections, being especially valuable in the treatment of tbose eczemas occurring in workers in various trades. It lessens itching, diminisbes redness and swelling, and dries up and beals oozing eczemas. It is contra-iadicated in infection of the skin, since suppuration can takc place and spread under the conl tar. The method of application is quite 
sirmple, eonsisting in applying a moderntely tbick layer of tbe tar to the afiected area with a not too stif brush, previous clcaning being necessary only in those cases attended by abuadant exudation aad the consequent
formation of thick crusts.

\title{
PATHOLOGY AND BAOTERIOLOGY.
}

\author{
UNDER THE CTAROE OP \\ WARFIELD T. LONGCOPE, MI.D.;

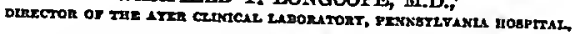 \\ AESISTED BT \\ G. CANBY ROBNSON, M.D. .

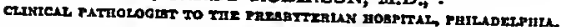

The Action of Lenkocytic Ertracts on the Course of Pnerumonia.-Tbe ides that leukocytes contain substances which, when present in a free state, migbt hnve a beneficial effect upon infectious processes originated with Hiss. His hypothesis was that the phagocytic cells contain an anti-endotoxin which proteeted the cells against the endotoxins of the baeteria wbich had been ingested. If this anti-endotoxin was liberated in a free state it would bave a beneficinl effect in the animal suffering from an infective process. This bypothesis was put to cxtensive experimental iavestigation by. Hiss and ZiNsser (Jour. Mfed. Reseorch, 1908 , xix, 323) by injections of leukocytie ertracts into animals after they had been inoculated with various pathogenic bacteria. This procedure gave such good results in effecting favorably the course of the infections in animals that it seemed justified to use the method as a means of treatment in human infectious processes. This method lins been used in man by Hiss and Zinsser, who have made, besides their original report, a second one oa the treatment of staphylococcus infections with leukocytic extract (Jour. Mfed. Reseorch, 1909, גX, 506). It has also been employed by LA3rBERT (AMrer. Jodr. MED. Sct., 1909, exxrvi, 506) in a variety of infectious processes in man. But the most extensive employment of this method of treatment in any one disease is that reported by Foorp and LvCss (Jour. Mnd. Reseorch, 1909, axi, 223), who used leukocytie extract as a method of treatment in 41 cases of pucumonia. Ieukocytes were obtnined from young rabbits after injections into the pleural and abdominal envities of $10 \mathrm{ccc}$ of a 5 per cent. aleuronat solution. The exudate thus obtained was washed and eentrifuged, the leukocytes were broken up by beating with a platinum loop, and extrueted with distilled water. Ten c.e. subeutnneously injected twice a day was the standard dose. As mueh as 20 e.e. three or four times a day was given without any harmful effeets. There were five deaths in these cases, giving a mortality of 12.5 per cent., which is to be contrasted with a mortality of 21 per eent. oceurring in cases of paeumonin treated by other methods under the same general conditions. All of the cases treated were lobar in type except tbree, which were cases of bronchopneumonia. Of the 5 cases that died, 2 were 